\title{
Performance Evaluation of Surface Irrigation Method under Cotton-Wheat Rotation
}

\author{
Amandeep Singh*, R.K. Jhorar, Sanjay Kumar and Narender Kumar \\ Department of Soil\& Water Engineering, COAE\&T, CCS Haryana Agricultural University, \\ Hisar-125004, Haryana, India \\ *Corresponding author
}

\begin{tabular}{|l|}
\hline Ke y w o r d s \\
$\begin{array}{l}\text { Border irrigation, Cotton, } \\
\text { Storage efficiency, Water } \\
\text { application efficiency, } \\
\text { Wheat }\end{array}$ \\
\hline Article Info \\
\hline $\begin{array}{l}\text { Accepted: } \\
\text { 10 April } 2018 \\
\text { Available Online: } \\
\text { 10 May } 2018\end{array}$ \\
\hline
\end{tabular}

A B S T R A C T

Performance evaluation of surface irrigation method was carried out for cotton and wheat fields in village Kirarkot (Sirsa). Water application, storage and distribution efficiency were estimated using measurements of soil moisture, infiltration characteristics, water advance and recession time during different irrigation events. Applied depth of irrigation was estimated based on infiltration opportunity time at different points in the selected border strips. Stratified soil profile (sandy loam: 0-30 cm and sandy clay loam: $30-120 \mathrm{~cm}$ ) of the selected fields caused the reduction in the infiltration rate to relatively very low value after 10-15 minutes creating favourable condition for uniformity of water application under surface irrigation. The water application efficiency of cotton field was $100 \%$ as applied depth of irrigation was less than the required depth throughout the field plots and in wheat field it varied from 79.37-95.68 \% indicating different degree of deep percolation loss. The observed water storage efficiency in different cotton fields varied from 72.92$90.08 \%$ indicating under irrigation, whereas, in wheat field, it was 100 percent as applied depth of irrigation was more than the required depth. For a given field plot (border strip) water application efficiency increased with increasing value of advance ratio suggesting the need to incorporate the concept of advance ratio in the design process of border irrigation. Water distribution efficiency of cotton fields (91.37-98.18\%) and wheat field $(82.26-96.13 \%)$ indicated a relatively high degree of uniformity of water application.

\section{Introduction}

Surface method of irrigation is the oldest and most common method of irrigation in which water flows over the soil surface and distributed over the field by gravity with the intention that the applied water infiltrates into the soil. This method looks very simple but the movement and distribution of water over the field is a very complex process due to spatial and temporal variations in soil infiltration and crop resistance. Typically, there may be four phases during a surface irrigation event: (i) water advance in the field, (ii) wetting or ponding (iii) depletion of ponded water, and (iv) recession of water along the reach of the field. Substantial part of the irrigation potential is not being fully utilized due to undesirable losses from the irrigation systems. This not only affects crop 
production but also results into resource degradation in the form of water logging and salinity problem. The efficiency with which water is applied under surface irrigation methods is often assessed through predefined performance parameters. Most common performance measures include application efficiency, storage efficiency and distribution uniformity. The actual performance of a surface irrigation depends on a number of design, management and site specific factors. The application efficiency depends upon userselected required depth of application. So, it is possible to obtain $100 \%$ application efficiency by selecting a high required depth of application (Anwar et al., 2016). Despite this progressive water shortage, farmers continue to use flooding irrigation. Poor management, uniformity and distribution of water have been cited as the most frequent problems of flooding irrigation, resulting in waterlogging, salinization and less water use efficiency (Ali and Mohammed, 2015).

Surface irrigation systems may become ineffective and inefficient due to physical constraints (improper land slopes, shallow soils, poor water supplies, etc.), inappropriate design and layout, or improper operation and management (Clemmens et al., 2008).

Surface irrigation systems need special attention not only due to potential risk of higher water losses but also due to higher costs of replacing with alternative methods (Holzapfel and Arumi, 2010). Several field scale factors (stream size, field size, soil type, irrigation time, land leveling, crop characteristics etc.) may determine the irrigation efficiency. Performance evaluation usually considers three point of view: (i) irrigation system performance as governed by effectiveness of physical system and operating decisions, (ii) uniformity of water application and (iii) the response of the crop to irrigation (Irmak, 2011).
Despite lot of emphasis being given to the adoption of sprinkler and micro irrigation system, majority of the irrigated area is still and will continue to be under different method of surface irrigation. Therefore, evaluation of the surface irrigation methods is essential to identify various management practices to improve the irrigation efficiency and/or uniformity of the system. Quantification of irrigation efficiency may help to identify suitable intervention to enhance the performance of irrigation systems. Therefore, the present study was planned with the objectives to quantify of water application efficiency of surface irrigation for cottonwheat crop rotation and to identify the design aspects of surface irrigation for improved water management.

\section{Materials and Methods}

Performance evaluation of border irrigation method was carried for cotton-wheat crops in village Kirarkot having $75^{\circ} 06^{\prime} 34^{\prime \prime} \mathrm{E}$ and $29^{\circ} 37^{\prime} 44^{\prime /} \mathrm{N}$ as longitude and latitude angle of Sirsa district of Haryana during the year 201415. Sirsa district is located in the western part of Haryana adjoining the state of Punjab and Rajasthan. The irrigation system in the district consists of a network of branch canals, distributaries, minors and watercourses through Bhakra Main Branch which originates from the Gobind Sagar Storage Reservoir located across the river Sutlej in the State of Himachal Pradesh. Groundwater is also being utilized for irrigation in the area. Existing field plots as used by the farmer (selected) were considered to make necessary measurements. In the cotton crop, farmers irrigated plots separately with canal and tubewell water since conjunctive use of water is not required due to rainfall. Whereas in wheat crop, canal and tubewell water was applied in the same plot. Layout and the code assigned to different plots is given in Figure 1 and Table 1. The irrigation schedule as practiced by the farmer was 
observed during study. During study period, the farmer applied seven irrigation to cotton crop including pre-sowing condition. However, following irrigation events were considered for performance evaluation of surface irrigation for cotton field i.e. Presowing irrigation (I), First post sown irrigation (II) and Irrigated at full vegetative growth (III). The farmer applied six irrigation to wheat crop including pre-sowing condition but II and III irrigation were considered for the performance evaluation.

For the measurement of field capacity, a field site with no vegetation on it was saturated with water and covered with a plastic cover to prevent evaporation. After 24-hour, soil water content was measured upto the depth of 120 $\mathrm{cm}$ for cotton field and $90 \mathrm{~cm}$ for wheat field. The measured moisture content was taken as moisture content corresponding to field capacity for different soil layers. The soil of the field was found as sandy loam upto $30 \mathrm{~cm}$ and sandy clay loam $30-120 \mathrm{~cm}$ for different soil layers. For the calculation of soil moisture, soil samples were taken before irrigation from soil depths of 0-15, 15-30, 30$60,60-90$ and $90-120 \mathrm{~cm}$ for cotton field and $0-15,15-30,30-60$ and $60-90 \mathrm{~cm}$ for wheat field. The soil samples were taken at three locations in each plot with the help of auger. Infiltration measurements were made for 60 minutes (at the interval of 5 minutes) before each irrigation using single cylinder infiltrometer. Measured infiltration data were fitted to the following form of Kostiakov infiltration equation (Michael, 2008):

$\mathrm{I}=\mathrm{kt}^{\mathrm{n}}(1)$

Where I: cumulate depth of water infiltrated (cm), k: constant of Kostiakov equation, t: cumulative time (minute) and $\mathrm{n}$ : exponent of Kostiakov equation. Bulk density was determined using mass volume relationship of the soil upto depth $120 \mathrm{~cm}(0-15,15-30,30-$
$60,60-90,90-120 \mathrm{~cm})$ for cotton field and $90 \mathrm{~cm}(0-15,15-30,30-60$ and $60-90 \mathrm{~cm})$ for wheat field. For the measurements of water advance and recession, wooden stakes were inserted at an interval of $20 \mathrm{~m}$ starting from upstream to the downstream end of the field to observe the time taken by the water to advance and recede at different position in the field.

The time taken by the water to reach to different stakes since turning on the inflow stream into the border strip was noted down. Likewise the time at which water receded from different stakes was also noted down. The difference between the time when the water front reaches a particular point along the field and the time at which the water recedes from the same point was taken as the infiltration opportunity time. Required net depth of the irrigation estimated by following formula:

$\mathrm{d}_{\mathrm{n}}=\frac{\left(\theta_{\mathrm{fc}}-\theta_{\mathrm{bi}}\right) \times \mathrm{Pb}_{\mathrm{bR}}}{100}$

Where $d_{n}$ : required net depth of the irrigation $(\mathrm{cm}), \Theta_{\mathrm{fc}}$ : moisture content at field capacity $(\%), \Theta_{\mathrm{bi}}$ : average moisture content before irrigation $(\%), \rho_{\mathrm{b}}$ : bulk density $\left(\mathrm{g} / \mathrm{cm}^{3}\right), \mathrm{RD}$ : root zone depth $(\mathrm{cm})$.

The water application efficiency $\left(E_{a}\right)$ was estimated as under (Michael, 2008):

$\mathrm{E}_{\mathrm{a}}=\frac{\mathrm{w}_{\mathrm{g}}}{\mathrm{w}_{\mathrm{f}}} \times 100$

Where $\mathrm{W}_{\mathrm{s}}$ : water stored in the root zone $(\mathrm{cm})$ and $\mathrm{W}_{\mathrm{f}}$ : water delivered to the field $(\mathrm{cm})$.

The water distribution efficiency $\left(E_{d}\right)$ indicates the degree of uniformity in the amount of the water infiltrated into the soil. It was estimated by following formula:

$\mathrm{E}_{\mathrm{d}}=100[1-(\mathrm{y} / \mathrm{d})](4)$ 
Where y: average absolute numerical deviation in depth of water stored from average depth stored during the irrigation $(\mathrm{cm})$ and $\mathrm{d}$ : average depth of water stored during irrigation $(\mathrm{cm})$

The water storage efficiency $\left(E_{s}\right)$ was estimated as under:

$\mathrm{E}_{\mathrm{s}}=\frac{\mathrm{w}_{\mathrm{g}}}{\mathrm{W}_{\mathrm{n}}} \times 100$

Where $\mathrm{W}_{\mathrm{s}}$ : water stored in the root zone $(\mathrm{cm})$ and $\mathrm{W}_{\mathrm{n}}$ : water needed to the field $(\mathrm{cm})$

Advance ratio $(\mathrm{R})$ was defined as under:

$\mathrm{R}=\frac{\operatorname{IOT}_{\mathrm{r}}}{\mathrm{t}_{\mathrm{a}}}(6)$

Where $\mathrm{IOT}_{\mathrm{r}}$ : required infiltration opportunity time computed based on $\mathrm{d}_{\mathrm{n}}$ and infiltration characteristics (minute) and $t_{\mathrm{a}}$ : time taken by the water advance to reach to the end of the border strip (minute).

\section{Results and Discussion}

\section{Required net depth of irrigation}

Estimation of required net depth of irrigation needs the information on field capacity, bulk density, moisture content before irrigation and root zone depth. The field capacity and bulk density upto 120 and $90 \mathrm{~cm}$ depth for cotton and wheat field was estimated. The field capacity in cotton and wheat field was ranging from 19.24 to 20.13 and 19.05 to $21.42 \%$, respectively in the root zone, whereas, the bulk density was ranging from 1.43 to 1.61 and 1.42 to $1.58 \%$, respectively. The surface layer showed relatively higher value of field capacity, which may be due to addition of FYM etc by the farmer. The required net depth $\left(d_{n}\right)$ of irrigation was more for cotton as compared to wheat (Table 2) for different irrigation events. One of the main reasons for higher value of $d_{n}$ for cotton is its deeper rooting system $(120 \mathrm{~cm})$ as compared to wheat $(90 \mathrm{~cm})$. The largest $d_{n}$ value for cotton crop was observed for pre-sowing irrigation. As expected, more moisture was depleted from shallow layers $(0-15 \mathrm{~cm})$ as compared to deeper layers. For instance before pre-sown irrigation, top $15 \mathrm{~cm}$ soil layer $(0-15 \mathrm{~cm})$ for $\mathrm{CC}_{1}$ plot showed $2.69 \mathrm{~cm}$ of moisture deficit $(1.79 \mathrm{~mm} / \mathrm{cm}$ depth) while the bottom $30 \mathrm{~cm}$ soil layer $(90-120 \mathrm{~cm})$ showed $2.05 \mathrm{~cm}$ of moisture deficit $(0.68 \mathrm{~mm} / \mathrm{cm}$ depth$)$. One of the reason for more moisture depletion from shallow depth is direct evaporation from surface layer. However similar trend was also observed at the time of full vegetative stage (IIIrd) irrigation, indicating that crop is also preferably using more moisture from shallow depths as compared to deeper depths.

\section{Infiltration characteristics}

Infiltration characteristics of soil plays important role in the performance of surface irrigation. The selected fields for the study showed relatively very high infiltration rate for first 10-15 minutes and then the infiltration rate decreased to relatively low value. Similarly, Dagadu and Nimbalkar (2012) was studied infiltration of different soils under different soil conditions and found that infiltration rates against time initially high and then decreased with time up to constant infiltration rate. The predicted behavior of some of the selected field plots for cumulative depth of infiltration for 60 minute is shown in Figure 2. It can be observed that cumulative depth of infiltration for the same duration of 60 minutes increased during the growing season of crops i.e. cumulative depth of infiltration was less before first irrigation and more for last irrigation. The dissimilar infiltration behavior of different plots during different irrigation events highlights the importance of infiltration measurement before 
each irrigation. For instance consider plot $\mathrm{CC}_{2}$, using the infiltration characteristics measured just before 3rd irrigation, the applied depth of water for 3rd irrigation at $0 \mathrm{~m}$ distance (beginning of the plot) was estimated as $8.28 \mathrm{~cm}$. If one uses the infiltration characteristics measured just before 1st irrigation to predict the applied depth of water for 3rd irrigation at $0 \mathrm{~m}$ it would be $7.61 \mathrm{~cm}$. Therefore it is important to have information on infiltration characteristics just before the irrigation.

\section{Water advance and recession}

The infiltration rate of the cotton field was higher before 3rd irrigation as compared to wheat field.

Therefore, one may expect faster water advance in wheat fields as compared to cotton fields. Larger value of advance time for wheat (slower water advance) during 3rd irrigation was due to two reasons: (i) larger width of wheat fields as compared to cotton fields (ii) more resistance to flow by closely grow wheat crop as compared to cotton crop (Table 3). The recession time for cotton fields was less than wheat fields. Smaller recession time for cotton fields as compared to wheat fields may be attributed to (i) higher infiltration rate in cotton fields as compared to wheat fields (ii) smaller advance time in cotton fields as compared to wheat fields (iii) smaller cut off time in cotton fields as compared to wheat fields.

\section{Infiltration opportunity time and applied depth of irrigation}

A properly designed border irrigation aims to achieve a uniform infiltration opportunity time throughout the entire length of the field to spread a uniform depth of water. Observed infiltration opportunity time (difference of recession and advance time), for most of the studied field plots, was quite uniform except at few location in some of the fields (Figure 3). Likewise the applied depth of irrigation, throughout different field plots also showed quite a uniform application. In general, observed infiltration opportunity time decreased with the growing season. However, decreased infiltration opportunity time could not cause corresponding decrease in the applied depth of water due to increased infiltration rate with growing season.

The estimated applied depth was always less than the depth of water delivered to the field. The difference in applied and delivered depth may be attributed to (i) conveyance losses in the channel reach from point of discharge measurement to the field (ii) spatial variability in the infiltration characteristics of the soil. The discharge measurements for canal water, was made in the lined portion of the water course which was about $150 \mathrm{~m}$ away from the irrigated field. The tubewell was located very close to irrigated fields. Accordingly the difference between the estimated applied depth and delivered depth is less in case of tubewell irrigation as compared to canal irrigation.

\section{Water application efficiency}

For cotton crop, the applied depth of water was less than the required depth for all irrigation events. As a typical example, the applied and required depth for plot $\mathrm{CC}_{1}$ is shown in Figure 4. Since there was no deep percolation loss due to under irrigation, the water application efficiency was $100 \%$ for all the cotton fields. On the other hand water application efficiency in wheat fields was less than $100 \%$ (Fig. 5). Lower water application efficiency in wheat fields indicates over irrigation resulting into deep percolation losses. The water application efficiencies of the wheat fields could be easily increased by suitably reducing the cutoff time. 
Fig.1 Layout of the experiment field (a) cotton using canal water (b) cotton using tubewell water (c) wheat using canal and tubewell water

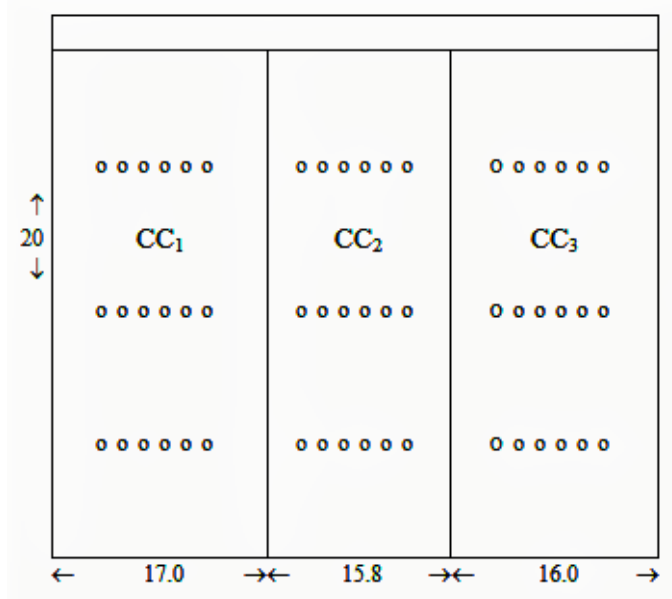

(a)

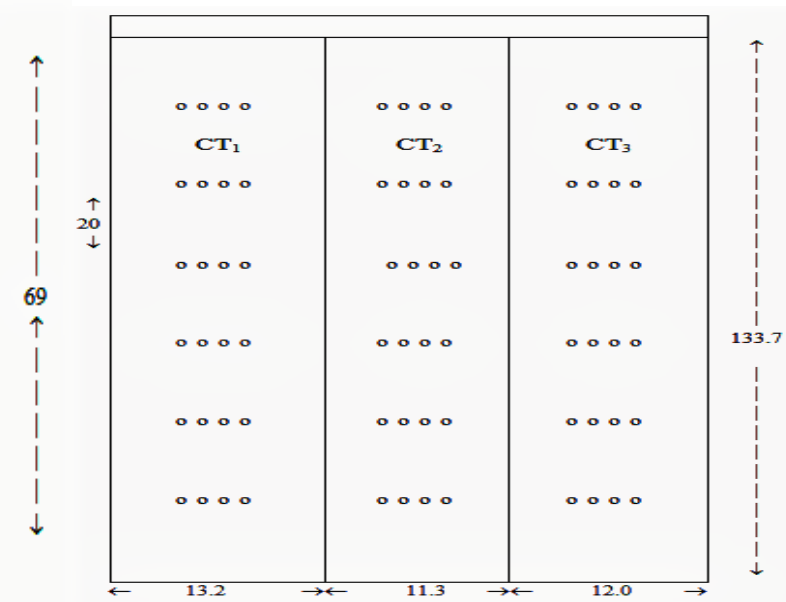

(b)

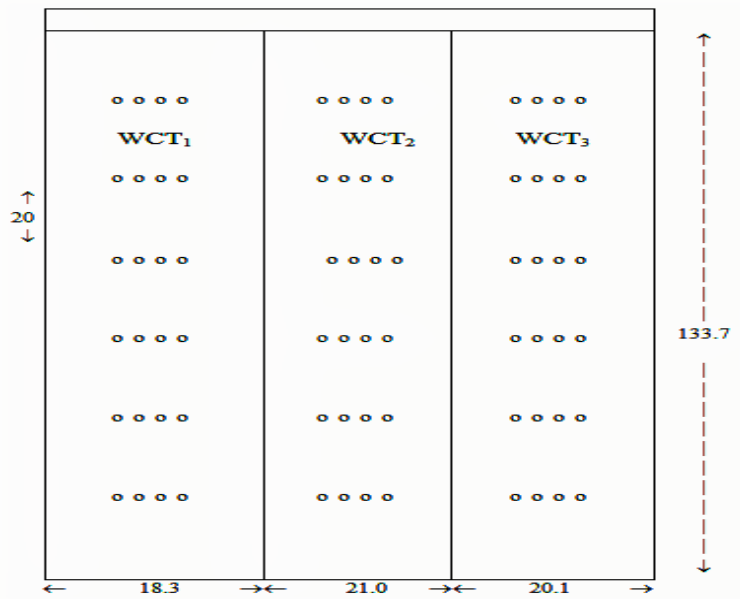

(c)

Fig.2 Predicted cumulative infiltration depth $\left(\mathrm{d}_{\mathrm{i}}\right)$ of selected field plots
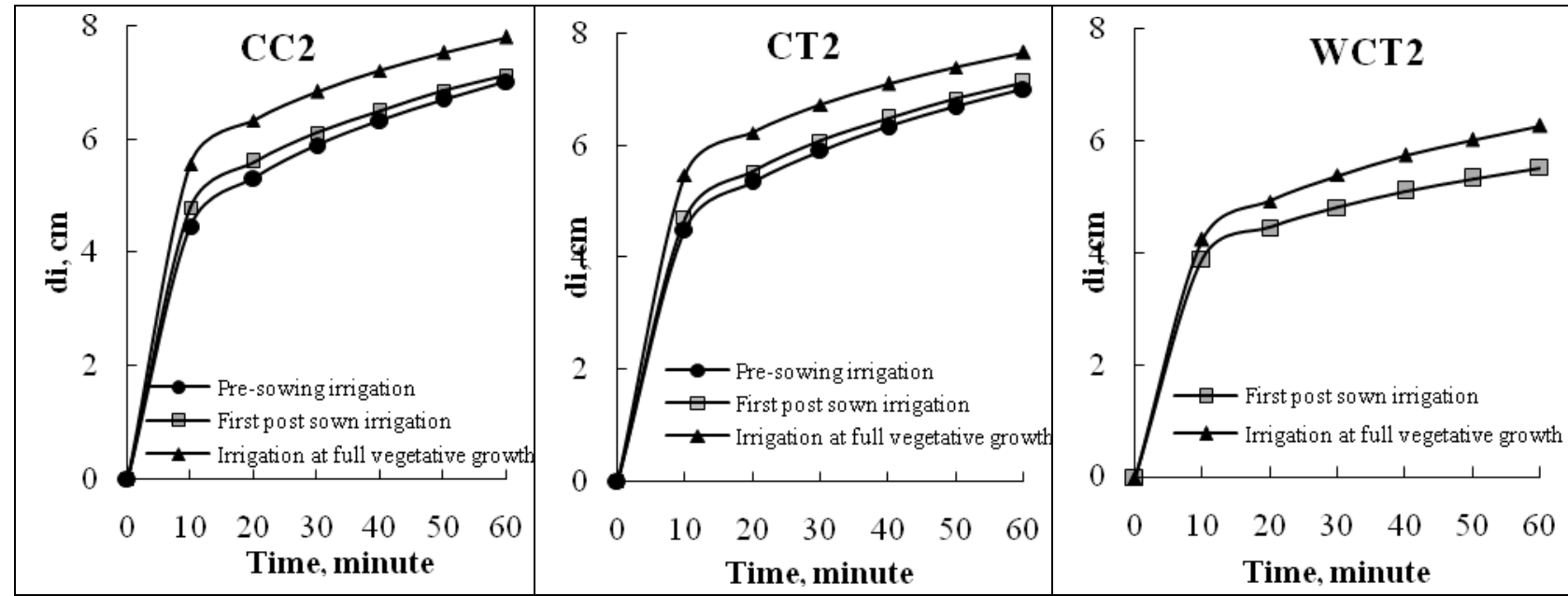
Fig.3 Advance $(\bullet)$ and recession $(\rtimes)$ curve for cotton field for different irrigation events when using tubewell water

\begin{tabular}{|c|c|c|}
\hline Pre-sowing irrigation & First post sown irrigation & $\begin{array}{l}\text { Irrigate at full vegetative } \\
\text { growth }\end{array}$ \\
\hline $\begin{array}{r}\mathbf{C C}_{3} \\
160 \\
120 \\
100 \\
80 \\
60 \\
40 \\
20 \\
0\end{array}$ & $\begin{array}{r}160 \\
140 \\
120 \\
100 \\
80 \\
60 \\
40 \\
20 \\
0\end{array}$ & $\begin{array}{r}140 \\
120 \\
100 \\
80 \\
60 \\
40 \\
20 \\
0 \\
0 \\
0 \\
0\end{array}$ \\
\hline Distance, $\mathbf{m}$ & $\begin{array}{r}250 \\
200 \\
200 \\
150 \\
100 \\
50 \\
0 \\
0 \\
0\end{array}$ & $\begin{array}{r}250 \\
200 \\
150 \\
100 \\
50 \\
0 \\
0 \\
0\end{array}$ \\
\hline & 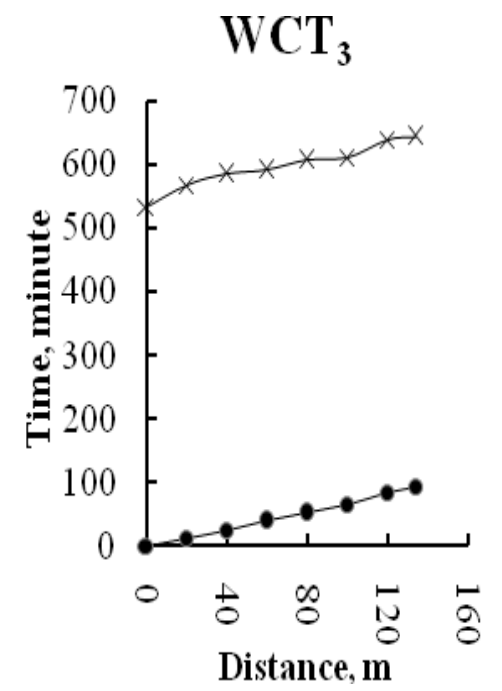 & 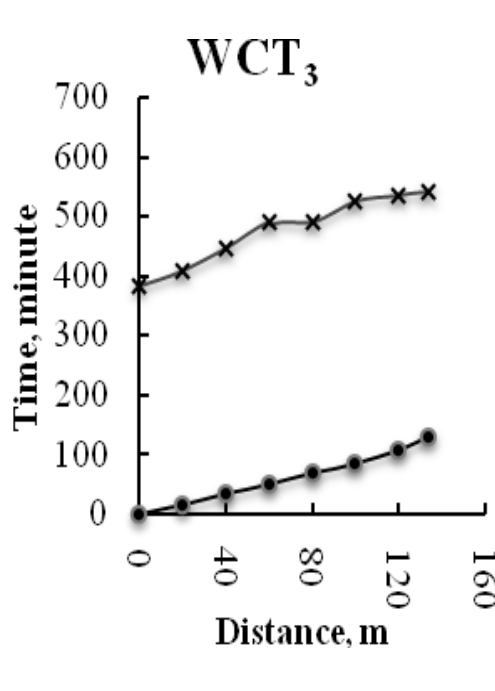 \\
\hline
\end{tabular}


Fig.4 Applied depth and required depth of irrigation forCC $\mathrm{C}_{1}$ for cotton field

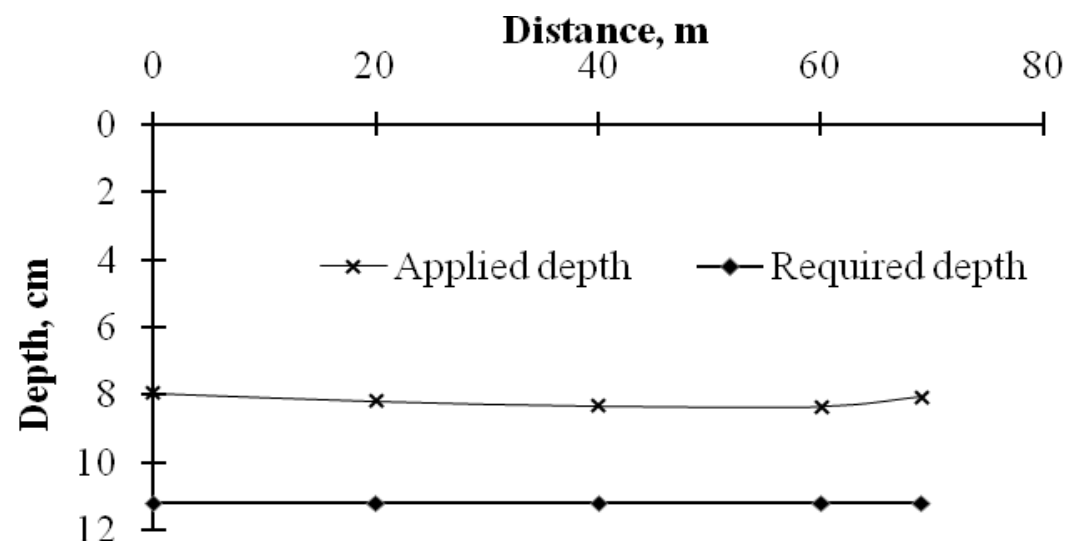

Fig.5 Water application efficiency for wheat crop for different irrigation events

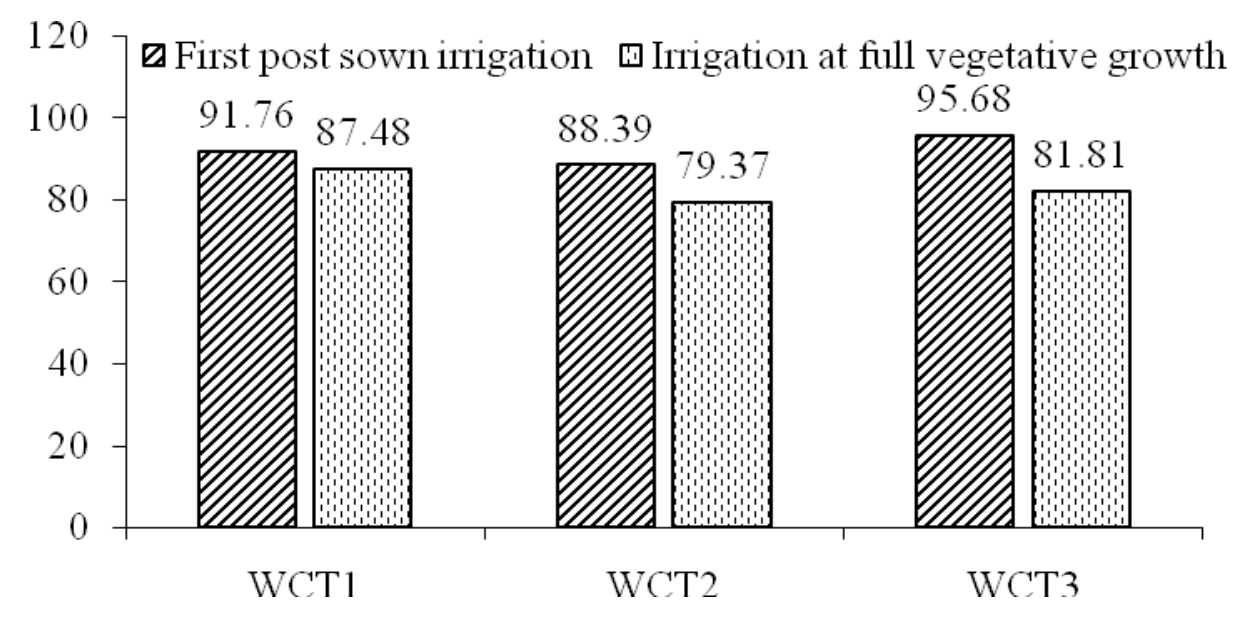

Fig.6 Water storage efficiency for cotton crop for different irrigation events

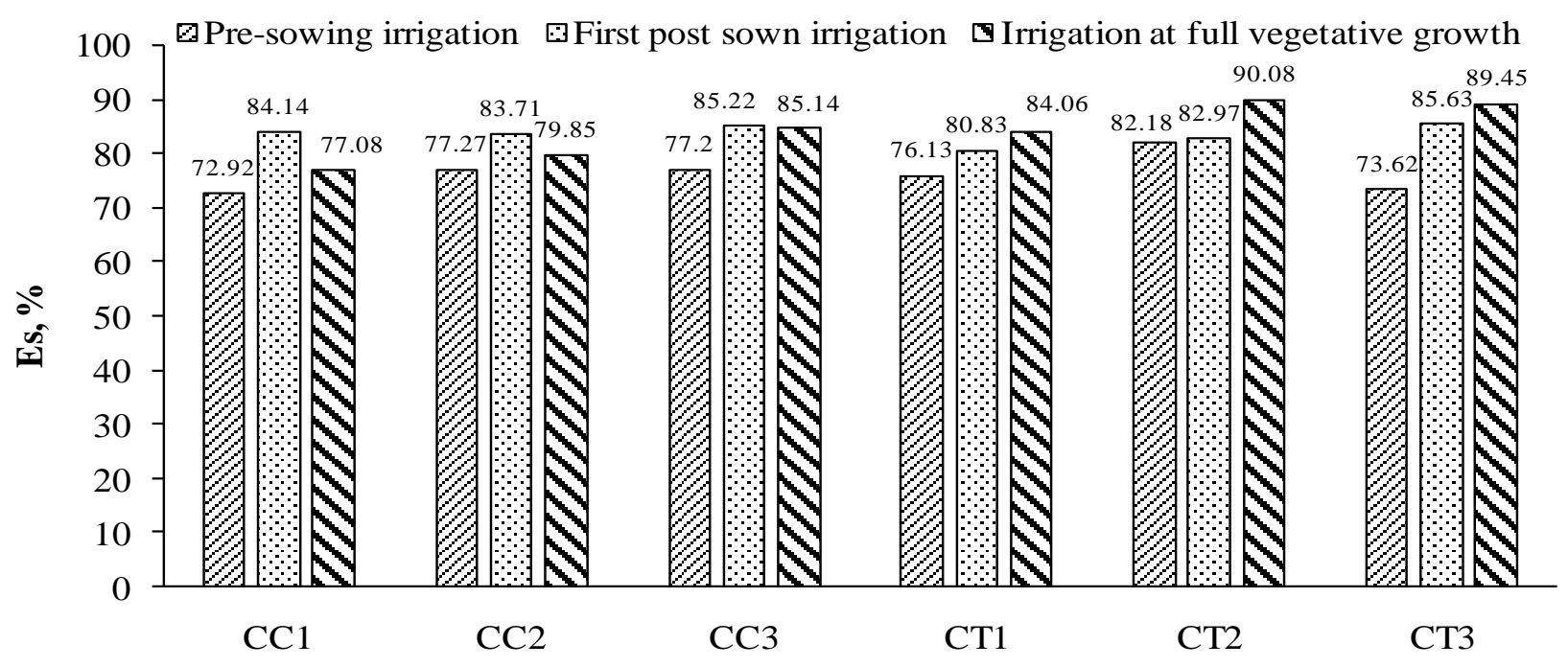


Fig.7 Applied depth and required depth for $\mathrm{WCT}_{1}$ (First post sown irrigation) for wheat field

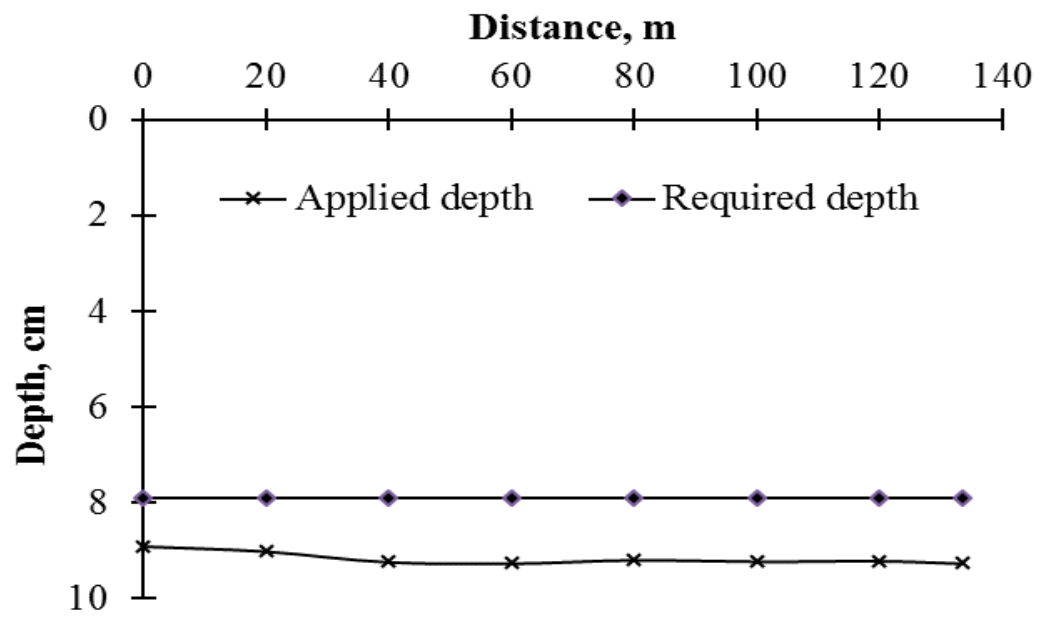

Table.1 Plot code and plot size for cotton and wheat crop

\begin{tabular}{|c|c|c|c|c|c|c|}
\hline \multirow{3}{*}{$\begin{array}{l}\text { Plot } \\
\text { No. }\end{array}$} & \multicolumn{4}{|c|}{ Cotton crop } & \multicolumn{2}{|c|}{ Wheat crop } \\
\hline & \multicolumn{2}{|c|}{ Canal water } & \multicolumn{2}{|c|}{ Tubewell water } & \multicolumn{2}{|c|}{ Canal and Tubewell water } \\
\hline & $\begin{array}{l}\text { Plot } \\
\text { code }\end{array}$ & $\begin{array}{c}\text { Plot size } \\
\mathrm{W}(\mathrm{m}) \mathrm{L} L(\mathrm{~m})\end{array}$ & $\begin{array}{l}\text { Plot } \\
\text { code }\end{array}$ & $\begin{array}{c}\text { Plot size } \\
\mathrm{W}(\mathrm{m}) \mathrm{xL}(\mathrm{m})\end{array}$ & $\begin{array}{l}\text { Plot } \\
\text { code }\end{array}$ & $\begin{array}{c}\text { Plot size } \\
\mathrm{W}(\mathrm{m}) \mathrm{xL}(\mathrm{m})\end{array}$ \\
\hline 1 & $\mathrm{CC}_{1}$ & $17.0 \times 69.0$ & $\mathrm{CT}_{1}$ & $13.2 \times 133.7$ & $\mathrm{WCT}_{1}$ & $18.3 \times 133.7$ \\
\hline 2 & $\mathrm{CC}_{2}$ & $15.8 \times 69.0$ & $\mathrm{CT}_{2}$ & $11.3 \times 133.7$ & $\mathrm{WCT}_{2}$ & $21.0 \times 133.7$ \\
\hline 3 & $\mathrm{CC}_{3}$ & $16.0 \times 69.0$ & $\mathrm{CT}_{3}$ & $12.0 \times 133.7$ & $\mathrm{WCT}_{3}$ & $20.1 \times 133.7$ \\
\hline
\end{tabular}

W: width of plot; L: length of plot

Table.2 Required net depth of irrigation for different field plots during different irrigation events

\begin{tabular}{|c|c|c|c|}
\hline \multirow{2}{*}{ Plots/Border } & \multicolumn{3}{|c|}{ Required net depth of irrigation (cm) } \\
\cline { 2 - 4 } & Pre-sowing irrigation & First post sown irrigation & $\begin{array}{c}\text { Irrigation at full } \\
\text { vegetative growth }\end{array}$ \\
\hline $\mathrm{CC}_{1}$ & 11.19 & Cotton & 10.82 \\
\hline $\mathrm{CC}_{2}$ & 10.56 & 9.71 & 10.52 \\
\hline $\mathrm{CC}_{3}$ & 10.44 & 9.70 & 10.03 \\
\hline $\mathrm{CT}_{1}$ & 11.94 & 9.81 & 10.60 \\
\hline $\mathrm{CT}_{2}$ & 11.39 & 11.06 & 10.18 \\
\hline $\mathrm{CT}_{3}$ & 11.60 & 10.98 & 10.24 \\
\hline & & 10.79 & 8.61 \\
\hline $\mathrm{WCT}_{1}$ & $*$ & 7.90 & 7.93 \\
\hline $\mathrm{WCT}_{2}$ & $*$ & 8.15 & 8.36 \\
\hline $\mathrm{WCT}_{3}$ & $*$ & 8.73 & \\
\hline
\end{tabular}

*After cotton harvesting, sufficient moisture was available in the soil. 
Table.3 Water advance and recession time (minute) during different irrigation events for cotton and wheat crop

\begin{tabular}{|c|c|c|c|c|c|c|}
\hline \multirow{2}{*}{$\begin{array}{l}\text { Distance } \\
\text { from } \\
\text { Upstrea } \\
\text { m end } \\
\text { (m) }\end{array}$} & \multicolumn{3}{|c|}{ Advance time } & \multicolumn{3}{|c|}{ Recession time } \\
\hline & $\begin{array}{c}\text { Pre- } \\
\text { sowing } \\
\text { irrigation }\end{array}$ & $\begin{array}{l}\text { First post } \\
\text { sown } \\
\text { irrigation }\end{array}$ & $\begin{array}{l}\text { Irrigation at } \\
\text { full vegetative } \\
\text { growth }\end{array}$ & $\begin{array}{l}\text { Pre-sowing } \\
\text { irrigation }\end{array}$ & $\begin{array}{l}\text { First post } \\
\text { sown } \\
\text { irrigation }\end{array}$ & $\begin{array}{l}\text { Irrigation at } \\
\text { Full vegetative } \\
\text { growth }\end{array}$ \\
\hline \multicolumn{7}{|c|}{ Field plot $\mathrm{CC}_{1}$} \\
\hline $\mathbf{0}$ & 0 & 0 & 0 & 105 & 99 & 86 \\
\hline 20 & 6.24 & 6.70 & 10.77 & 122 & 117 & 101 \\
\hline 40 & 15.48 & 17.63 & 23.11 & 139 & 133 & 118 \\
\hline 60 & 25.96 & 29.19 & 36.52 & 151 & 140 & 132 \\
\hline 69 & 30.28 & 32.24 & 39.65 & 140 & 134 & 123 \\
\hline \multicolumn{7}{|c|}{ Field plot $\mathrm{CT}_{1}$} \\
\hline 0 & 0 & 0 & 0 & 166 & 151 & 137 \\
\hline 20 & 7.31 & 8.44 & 9.61 & 184 & 171 & 166 \\
\hline 40 & 15.99 & 17.39 & 21.87 & 217 & 199 & 173 \\
\hline 60 & 24.62 & 29.70 & 36.46 & 229 & 214 & 160 \\
\hline 80 & 33.83 & 43.80 & 51.58 & 249 & 243 & 192 \\
\hline 100 & 42.69 & 56.50 & 61.42 & 238 & 256 & 210 \\
\hline 120 & 54.08 & 69.08 & 69.86 & 266 & 258 & 230 \\
\hline 133.7 & 65.32 & 79.67 & 78.41 & 261 & 255 & 226 \\
\hline \multicolumn{7}{|c|}{ Field plot $\mathrm{WCT}_{1}$} \\
\hline 0 & - & 0 & 0 & & 453 & 372 \\
\hline 20 & - & 10.64 & 12.61 & - & 489 & 421 \\
\hline 40 & - & 21.98 & 28.18 & - & 554 & 446 \\
\hline 60 & - & 35.66 & 43.27 & - & 575 & 468 \\
\hline 80 & - & 49.45 & 61.76 & - & 571 & 486 \\
\hline 100 & - & 62.65 & 79.86 & - & 593 & 480 \\
\hline 120 & - & 74.18 & 99.69 & - & 601 & 509 \\
\hline 133.7 & - & 84.18 & 117.61 & - & 625 & 514 \\
\hline
\end{tabular}


Table.4 Water distribution efficiency and advance ratio for cotton and wheat fields for different irrigation events

\begin{tabular}{|c|c|c|c|c|}
\hline \multirow[t]{2}{*}{ Plot } & Irrigation events & $\mathrm{IOT}_{\mathbf{r}}$ & $\begin{array}{l}\text { Advance } \\
\text { time }\end{array}$ & $\begin{array}{c}\text { Advance } \\
\text { ratio }\end{array}$ \\
\hline & & $(\min )$ & (min) & \\
\hline \multirow[t]{3}{*}{$\mathrm{CC}_{1}$} & Pre-sowing irrigation & 365.17 & 30.28 & 12.06 \\
\hline & First post sown irrigation & 216.87 & 32.24 & 6.73 \\
\hline & Irrigation at full vegetative growth & 338.91 & 39.65 & 8.55 \\
\hline \multirow[t]{3}{*}{$\mathrm{CC}_{2}$} & Pre-sowing irrigation & 305.85 & 27.82 & 10.99 \\
\hline & First post sown irrigation & 241.21 & 27.55 & 8.75 \\
\hline & Irrigation at full vegetative growth & 294.69 & 38.30 & 7.69 \\
\hline \multirow[t]{3}{*}{$\mathrm{CC}_{3}$} & Pre-sowing irrigation & 317.44 & 28.36 & 11.19 \\
\hline & First post sown irrigation & 208.82 & 29.53 & 7.07 \\
\hline & Irrigation at full vegetative growth & 200.83 & 37.73 & 5.32 \\
\hline \multirow[t]{3}{*}{$\mathrm{CT}_{1}$} & Pre-sowing irrigation & 561.26 & 65.32 & 8.59 \\
\hline & First post sown irrigation & 464.73 & 79.67 & 5.83 \\
\hline & Irrigation at full vegetative growth & 351.07 & 78.41 & 4.48 \\
\hline \multirow[t]{3}{*}{$\mathrm{CT}_{2}$} & Pre-sowing irrigation & 422.60 & 52.47 & 8.05 \\
\hline & First post sown irrigation & 388.93 & 71.42 & 5.44 \\
\hline & Irrigation at full vegetative growth & 272.46 & 71.33 & 3.81 \\
\hline \multirow[t]{3}{*}{$\mathrm{CT}_{3}$} & Pre-sowing irrigation & 841.59 & 57.67 & 14.59 \\
\hline & First post sown irrigation & 358.26 & 73.85 & 4.85 \\
\hline & Irrigation at full vegetative growth & 272.98 & 85.46 & 3.19 \\
\hline \multirow[t]{2}{*}{$\mathrm{WCT}_{1}$} & First post sown irrigation & 244.40 & 84.18 & 2.90 \\
\hline & Irrigation at full vegetative growth & 261.30 & 117.61 & 2.21 \\
\hline \multirow[t]{2}{*}{$\mathrm{WCT}_{2}$} & First post sown irrigation & 416.07 & 92.18 & 4.40 \\
\hline & Irrigation at full vegetative growth & 169.56 & 134.29 & 1.26 \\
\hline \multirow[t]{2}{*}{$\mathrm{WCT}_{3}$} & First post sown irrigation & 500.26 & 93.96 & 5.32 \\
\hline & Irrigation at full vegetative growth & 193.98 & 129.60 & 1.50 \\
\hline
\end{tabular}

The lower water application efficiencies in wheat fields during IIIrd irrigation is due to increased time difference between the advance and cutoff time. This further implies the need for suitable reduction of cutoff time in the selected wheat fields. Horst et al., (2005) tested several alternatives to enhance the performance of furrow irrigation system and founded application efficiency upto 80 percent and distribution uniformity upto $83 \%$. Eldeiry et al., (2005) observed that with proper selection of furrow length and inflow discharge, relatively high application efficiency (80-90\%) could be obtained in clay soils.

\section{Advance ratio}

Advance ratio defined as the ratio of required infiltration opportunity time $\left(\mathrm{IOT}_{\mathrm{r}}\right)$ to the advance time along with the respective value of water distribution efficiencies (Table 5). In general, for a given plot higher value of the advance ratio caused higher water application efficiency and less deep percolation losses. In case of cotton field, the water application 
efficiency was 100 percent, thus, the decrease in advance ratio from pre-sowing irrigation to irrigation at full vegetative growth has shown no impact on the water application efficiency. Whereas, in wheat fields, the decrease in advance ratio from first post sown irrigation to irrigation at full vegetative growth also decreased the water application efficiency. For instance for plot $\mathrm{WCT}_{3}$, advance ratio for First post sown irrigation to Irrigation at full vegetative growth were 5.32 and 1.50 (Table 5) with corresponding water application efficiencies 95.68 and $81.88 \%$ respectively (Figure 5). Thus, for design of border irrigation method, the concept of advance ratio should be incorporated in the design process to achieve desirable level of water distribution and water application efficiencies. Darouich et al., (2012) studied that adopting more advanced and costly irrigation technologies requires appropriate economic incentives, training of farmers and an institutional framework able to support the sustainable use of water in irrigation.

\section{Water storage efficiency}

The farmer under irrigated all the cotton fields, thus, the water storage efficiency of cotton fields was less than $100 \%$ (Fig. 5). During pre-sown irrigation, the lowest and highest water storage efficiency was recorded as 72.92 and $82.18 \%$ in CC1 and CT2, respectively. Similarly, during irrigation at full vegetative growth, the lowest and highest water storage efficiency was recorded as 77.08 and $90.08 \%$ in CC1 and CT2, respectively. In case of wheat fields, applied depth of water was always more than the required depth throughout all the plots during different irrigation events, thus, the storage efficiency for wheat fields was $100 \%$. In $\mathrm{WCT}_{1}$, required depth for first post sown irrigation was $7.90 \mathrm{~cm}$ while the minimum applied depth was $8.79 \mathrm{~cm}$ at the upstream end (Figure 6). Abdelmageed (2013) analyzed the performance of surface irrigation method and observed water storage efficiency be higher $(62.75 \%)$ for siphon irrigated fields as compared to gated pipe $(55.25 \%)$ irrigated fields.

Stratified soil profile (sandy loam: 0-30 $\mathrm{cm}$ and sandy clay loam: $30-120 \mathrm{~cm}$ ) of the selected fields caused the infiltration rate to reduce to relatively very low value after 10-15 minutes creating favourable condition for uniformity of water application under surface irrigation, particularly where the required infiltration opportunity time is more than 15 minutes.

Periodic moisture measurements showed that wheat and cotton utilised more water from shallow depths as compared to deeper depths. Changes in the cumulative depth of water infiltrated, for a given time, during the growing season of wheat and cotton suggested the need to determine infiltration characteristics immediately before each irrigation for performance evaluation. Observed advance time increased during the growing season due to increased infiltration rate and increased resistance to flow by the growing crops.

Observed water application efficiency of different cotton fields was $100 \%$ as applied depth of irrigation was less than the required depth throughout the field plots. Observed water application efficiency of different wheat fields varied from 79.37-95.68 \% indicating different degree of deep percolation loss. Further analysis showed the possibility of decreasing the cutoff time in wheat fields to reduce deep percolation losses

Observed water storage efficiency in different cotton fields varied from 72.92-90.08\% indicating different degrees of deficit irrigation to cotton crop. Observed water storage efficiency in different wheat fields 
was $100 \%$ as applied depth of irrigation was more than the required depth throughout the field plots.

For a given field plot (border strip), water application efficiency increased with increasing value of advance ratio suggesting the need to incorporate the concept of advance ration in the design process of border irrigation.

\section{References}

Abdelmageed N B. 2013. Performance assessment of some developed surface irrigation methods. International Journal of Water Resources \& Environmental Engineering., 5(7), 399409.

Ali A M and Ahmed Mohammed, S. H. 2015. Performance evaluation of gated pipes technique for improving surface irrigation efficiency in maize hybrids. Agricultural Sciences., 6: 550-570.

Amer K H H. 2009. The possibility of improving surface irrigation with blocked end on sparse grape trees. Misr J. Ag. Eng., 26(2): 836-865.

Anwar A A, Ahmad W, Bhatti M T and Haq $\mathrm{Z}$ U. 2016. The potential of precision surface irrigation in the Indus basin irrigation system. Irrigation Science., $1-18$

Clemmens A J, Allen R G and Burt C M. 2008. Technical concepts related to conservation of irrigation and rainwater in agricultural systems. Water Resources Research., 44(7): Art.no. W00E03.
Dagadu J S and Nimbalkar P T. 2012. Infiltration Studies of Different Soils under Different Soil Conditions and Comparison of Infiltration Models with Field Data. International Journal of Advanced Engineering Technology, 3(2): 54-157.

Darouich H, Goncalves J M, Muga A and Pereira L S. 2012. Water saving vs. farm economics in cotton surface irrigation: An application of multicriteria analysis. Agricultural Water Management, 115: 223-231.

Eldeiry AA, Garcia L A, El-Zaher A S A and Kiwan M El-Sherbini. 2005. Furrow irrigation system design for clay soils in arid region. Applied Engineering in Agriculture, 21(3): 411-420.

Holzapfel E A and Arumi J L. 2010.Tecnología de manejo de aguaparauna agricultura intensive sustentable. Editorial Universidad de Concepción, Concepción, Chile: 209.

Horst M G, Shamutalov S S, Pereira L Sand Goncalves J M. 2005. Field assessment of the water saving potential with furrow irrigation in Fergana, Areal Sea basin. Agricultural Water Management, 77: 210-231.

Irmak S. 2011. Dynamics of nocturnal, daytime, and sum-of-hourly evapotranspiration and other surface energy fluxes over non stressed maize canopy. Journal of Irrigation and Drainage, 137(8): 475-490.

Michael A M. 2008. Irrigation Theory and Practice. $2^{\text {nd }}$ Ed; Vikas Publishing House Pvt. Ltd.

\section{How to cite this article:}

Amandeep Singh, R.K. Jhorar, Sanjay Kumar and Narender Kumar. 2018. Performance Evaluation of Surface Irrigation Method under Cotton-Wheat Rotation. Int.J.Curr.Microbiol.App.Sci. 7(05): 1014-1026. doi: https://doi.org/10.20546/ijcmas.2018.705.126 